Gastrointestinal stromal tumours (GISTs) account for $0.1-3 \%$ of all gastrointestinal cancers. Although nausea, emesis, abdominal pain, GIS haemorrhage, and non-specific symptoms associated with metastatic disease are common, asymptomatic cases are not rare. They are located in the stomach in approximately $60-70 \%$ of cases, and in the small intestine in $20-30 \%$ of cases. Gastrointestinal stromal tumours can be seen synchronously or metachronously with other epithelial cancers. The co-occurrence of colon adenocarcinomas and GISTs in the small intestine is not common. The genetic pathways in the tumourigenesis of two different neoplasms (GIST and colorectal adenocarcinoma) being different was suggested as a probable cause; however; although the number of cases is limited, some researchers have reported that they could not rule out the possibility that this association is not coincidental. Herein we present a patient who was concomitantly diagnosed with a GIST as a result of an ileal lesion biopsy performed during surgery for colon adenocarcinoma.

Key words: adenocarcinoma, gastrointestinal stromal tumours, small intestine.

\section{Small intestine-derived gastrointestinal stromal tumour diagnosed synchronously with colon adenocarcinoma: a case report and review of the literature}

Ozgur Tanriverdi', Nezih Meydan'1, Sabri Barutca', Gokhan Sargin², Canten Tataroglu $\mathbf{u}^{3}$, Ibrahim Meteoglu ${ }^{3}$

${ }^{1}$ Adnan Menderes University, Faculty of Medicine, Department of Medical Oncology, Aydın, Turkey

2Adnan Menderes University, Faculty of Medicine, Department of Internal Medicine, Aydın, Turkey

${ }^{3}$ Adnan Menderes University, Faculty of Medicine, Department of Pathology, Aydın, Turkey

\section{Introduction}

Although diagnosed with increasing frequency, gastrointestinal stromal tumours (GISTS) are rare among all gastrointestinal system (GIS) tumours. These mesenchymal tumours, which are characterized by positively staining with CD117 (c-kit protein), account for 0.1-3\% of all GIS cancers. These tumours can arise from anywhere in the GIS. The stomach is the primary location in approximately $60-70 \%$ of cases, followed by the small intestine in $20-30 \%$ of cases. Gastrointestinal stromal tumours located in the small intestine are more aggressive than other types [1-3]. Although nausea, emesis, abdominal pain, GIS haemorrhage, and non-specific symptoms associated with metastatic disease are common, asymptomatic cases are not uncommon [1]. The most important prognostic criteria are tumour size and mitotic count [1-3].

Carcinogenesis and pathogenesis of these tumours are not clearly understood, because they can be observed along with other tumours and this cooccurrence is not infrequent. Most commonly the diagnosis is made coincidentally during surgery performed for other reasons. Some researchers have reported that the genetic features of tumour progression are the most probable cause of this co-occurrence [4]. Although it is seen more often with GIS malignancies, a review of the literature showed that this co-occurrence is more common with stromal tumours of the stomach and less common with GISTs of small intestine origin. Herein we present a patient who was diagnosed with a GIST based on histopathological analysis of a mass observed in the ileum during surgery performed for a caecum adenocarcinoma. We discuss the patient alongside data from a small number of case reports in the literature.

\section{Case report}

A 78-year-old male patient was first taken to another surgery clinic due to complaints of lethargy, constipation, and abdominal discomfort. Abdominal computed tomography (CT) showed a $4 \times 3 \mathrm{~cm}$ soft tissue mass in the right iliac fossa near the caecum (reminiscent of intestinal wall thickening), fluid collection in the caecum, and extensive enlargement of the caecum (Fig. 1). A 3-4 cm partially ulcerated irregular lesion was observed in the caecum endoscopically and analysis of the biopsy showed a colon adenocarcinoma. Distant organ metastases were not observed during the grading procedure. Exploratory laparotomy showed over-dilated small intestinal segments 


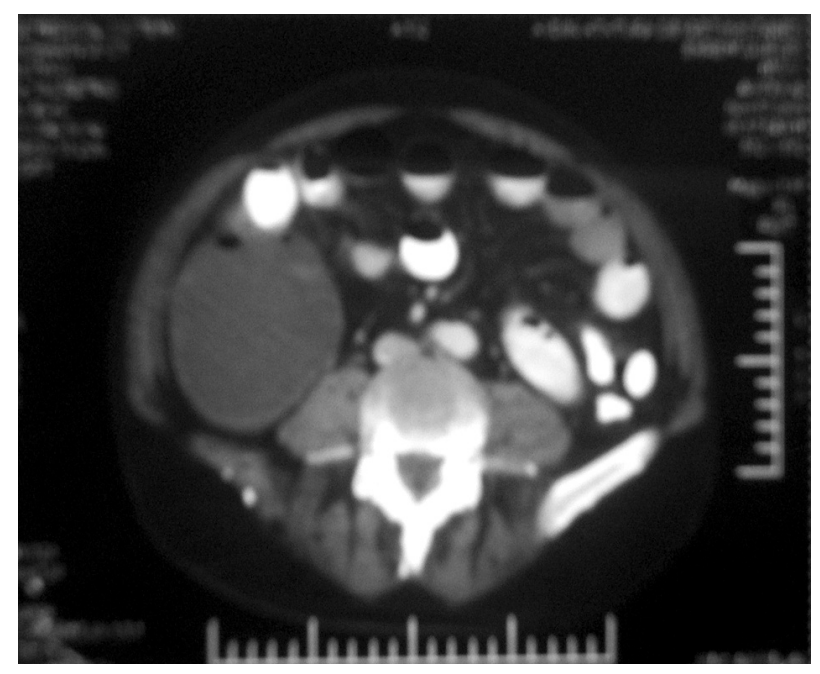

Fig. 1. CT of abdomen shows widely distributed free air and fluid level in the ileum and caecum

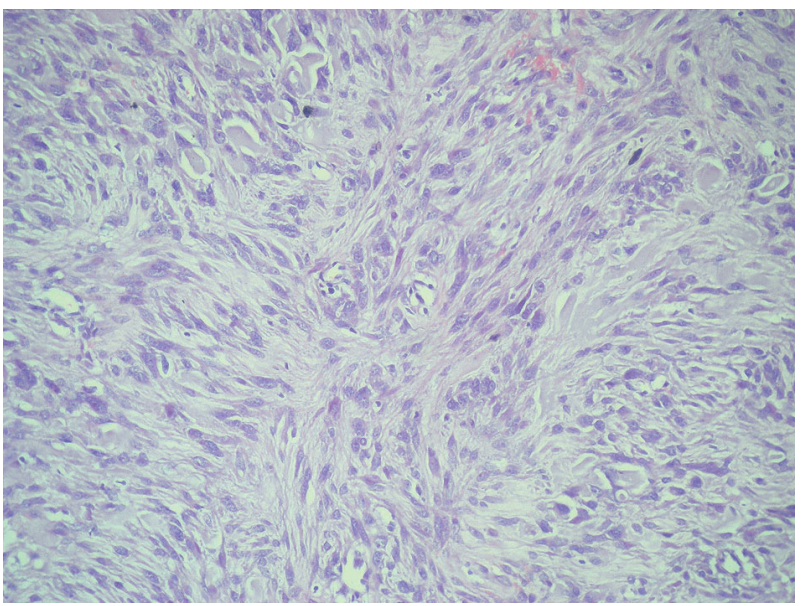

Fig. 3. The image shows the ileal gastrointestinal stromal tumour (HE, magnification 20x)

and a $2 \mathrm{~cm}$ tumoural mass implanted in the serosa of the small intestine $20 \mathrm{~cm}$ from the ligament of Treitz, as well as an approximately $5 \mathrm{~cm}$ tumoural mass that obstructed the lumen at the hepatic flexure during retrograde internal decompression. Right hemicolectomy and wedge resection for the implanted lesion in the small intestine was performed. Histopathological analysis of the tumour of the colon showed a well-differentiated adenocarcinoma (pT3N2MO, Dukes stage C2) (Fig. 2). The second tumoural mass that extended to the serosa from the small intestine mucosa and lamina propria diffusely stained with CD117 (c-kit protein), and primarily consisted of spindle-shaped and sparse epithelial cells (Fig. 3 and 4). Histopathological analysis showed it to be located at the surgical border. The tumour cells that were diagnosed as GIST did not stain with Ki67, and necrosis and mitosis were not observed.

The patient was referred to our clinic for adjuvant therapy. His medical history was unremarkable, except for hypertension. Excluding the last 5 years, he had smoked 1 pack of cigarettes each day for 40 years. He did not use alcohol. His performance was Eastern Cooperative Oncology Group

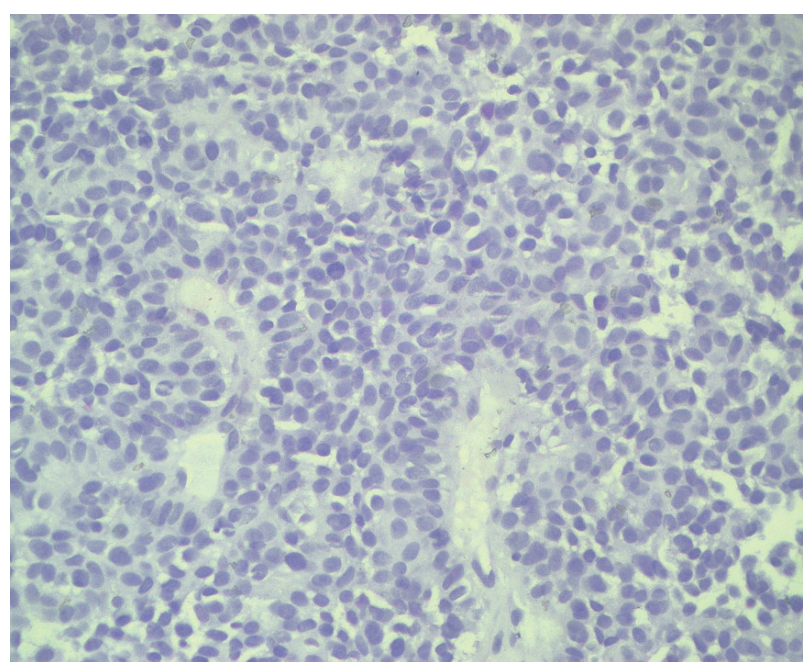

Fig. 2. Image showing the well-differentiated adenocarcinoma of the caecum ( $\mathrm{HE}$, magnification $10 \times$ )

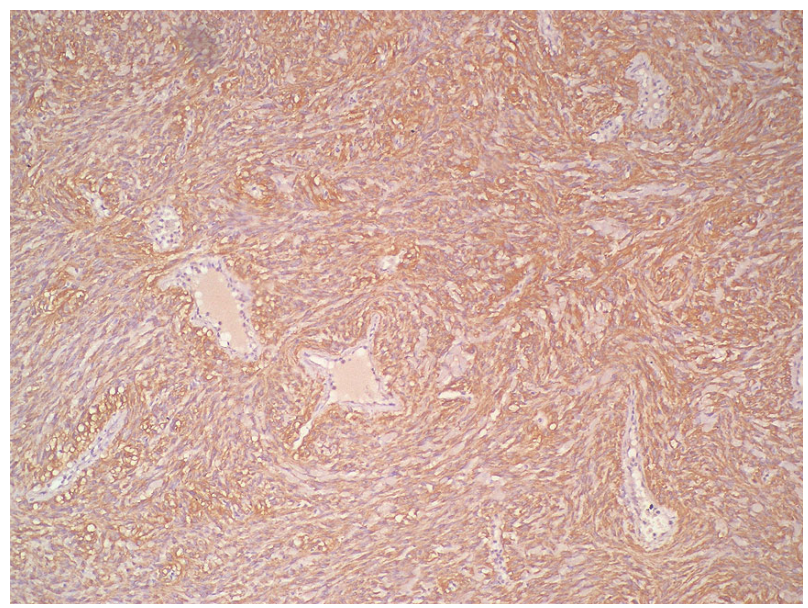

Fig. 4. The picture demonstrates the CD 117 positive ileal tumour (c-kit positive, magnification 10x)

(ECOG) 1, blood pressure was 135/80 $\mathrm{mm} \mathrm{Hg}$, and heart rate was 92 bpm and rhythmic. There was no pathological finding on physical examination except for $1 / 6$ systolic mesocardial murmur. Laboratory data were haemoglobin $10.2 \mathrm{~g} / \mathrm{dl}$ and haematocrit 30.1\%. Other laboratory parameters were within the normal range. In an immunohistochemical re-evaluation by the pathology department, focal positive centres of the colon adenocarcinoma were observed with CD117 (c-kit protein) staining (Fig. 5 and 6). Adjuvant systemic therapy with modified FOLFOX6 (oxaliplatin $85 \mathrm{mg} \cdot \mathrm{m}^{-2} \cdot \mathrm{d}^{-1}$, folinic acid $400 \mathrm{mg} \cdot \mathrm{m}^{-2} \cdot \mathrm{d}^{-1}$, and fluorouracil $2800 \mathrm{mg} \cdot \mathrm{m}^{-2} \cdot 48 \mathrm{~h}$ ) was started once every 2 weeks. At the 2 -month post-surgical follow-up there was no metastasis or recurrence, and systemic adjuvant therapy was continued. Imatinib $400 \mathrm{mg} \mathrm{d}^{-1}$ was initiated for the histopathological residual GIST. The patient was followed up for 14 months without recurrence or metastasis.

\section{Discussion}

Gastrointestinal stromal tumours were first described in 1983 by Mazur et al. and are classified as a subgroup of GIS 

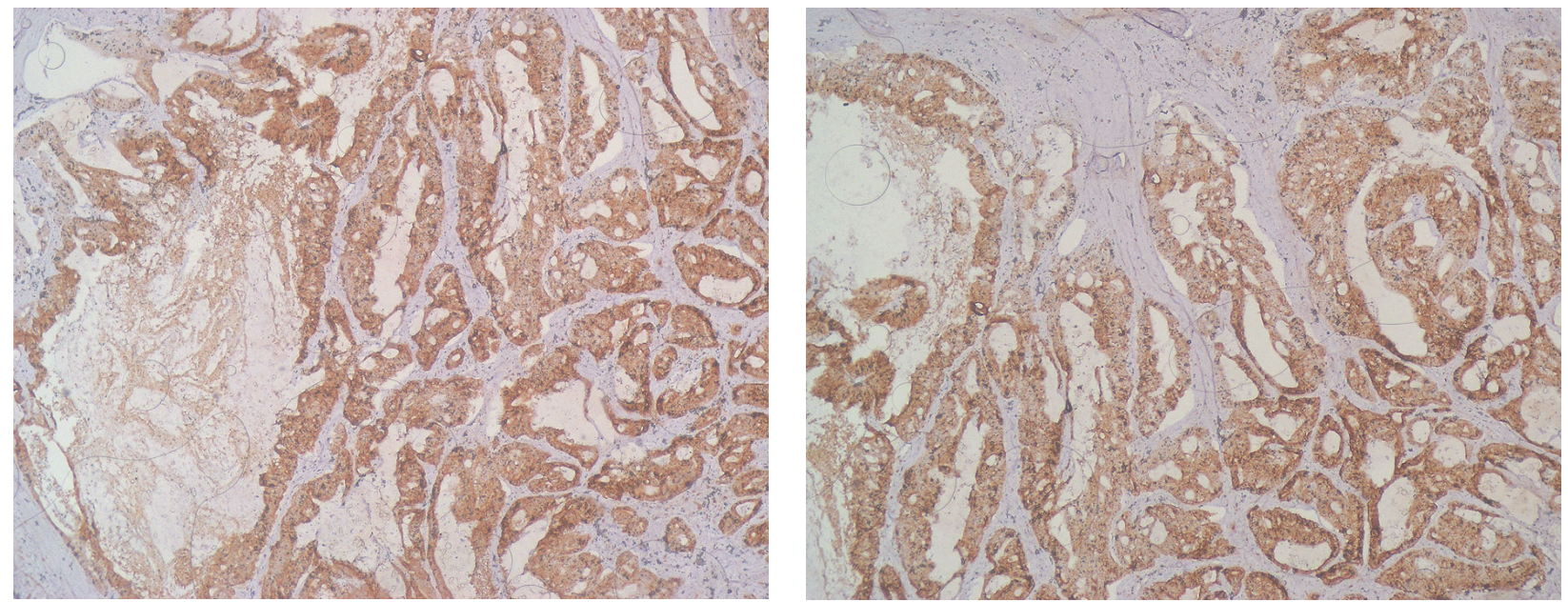

Fig. 5 and 6. Focal staining with c-kit in the colonic adenocarcinoma cell (c-kit positive, magnification 10×)

sarcomas [5]. Kindblom et al. reported that stromal tumours originate from Cajal cells, which regulate GIS motility and autonomic nerve functions. The fact that Cajal cells exhibited CD117 (c-kit protein) and CD34 expression led the researchers to conclude that stromal tumours originated from these cells [6].

Gastrointestinal stromal tumours other than type I neurofibromatosis, Carney triad, and familial cases usually occur as a single lesion. These tumours are rarely seen along with other solid tumours [7]. The co-occurrence of GISTs with other malignancies is synchronous or metachronous. Nearly $33 \%$ of all stromal tumours are diagnosed incidentally during investigation or therapy for other diseases. Nilsson et al. reported that 22 of 60 GIST patients were diagnosed during therapy for a different intra-abdominal tumour [8]; this ratio was 19 of 74 in Au et al.'s series [9]. The presented case was diagnosed with a GIST during routine abdominal exploration performed during elective surgery for colon cancer.

Köver et al. reported that 7 of 43 patients with GIST had an accompanying solid tumour [10], whereas Urbanczyk et al. reported 7 of 200 [11] and Agaimy et al. reported 18 of 97 patients had accompanying solid tumours [1]. In another study by Agaimy et al., it was reported that 258 of 2809 GIST patients (9.2\%) had a second tumour [2]. In that study 14 reports published before 2006 and their own patients were analysed, and it was determined that 444 of 4777 GIST patients (9.3\%) had a second solid tumour. Moreover, when they included the other 36 patients from case reports the co-occurrence rate of solid tumours and GIST ranged between $4.5 \%$ and $33 \%$. Among the reports published after 2006, irrespective of the origination site Liszka et al. reported that 22 of 82 GIST patients had a second epithelial malignant tumour [12]. Goncalves et al. determined a ratio of 14 of 101 [13], Bulusu et al. found 21 of 150 [14], and Yavuzer et al. reported that 5 of 22 GIST patients had a second epithelial malignant tumour [15]. In consideration of these series, it could be concluded that the mean co-occurrence rate of solid tumours with GISTs is $15.7 \%$ (range 3.5-26.8\%). These studies show that GIS cancers are the most common tumours that accompany GISTs (47\%) [1, 2]. Colorectal cancers are the most common (22\%) of all GIS cancers, followed by stomach (19\%), and oesophageal cancers (2\%). Other secondary tumours that accompany GISTs include prostate, lymphoma/leukaemia, breast, kidney, lung, female genitalia, soft tissue, and bone sarcomas, carcinoid tumours, and pancreatic cancers. Moreover, Agaimy et al. reported that the incidence of multiple secondary malignancies is $1.03 \%[2]$.

Gastrointestinal stromal tumours in the stomach are most frequently associated with other neoplasms (60\%). This may be due to the fact that most stromal tumours originate from the stomach. Some researchers have suggested that this coincidence is probably linked to Helicobacter pylori infection $[3,16]$. Wronski et al. reported that only 4 of 28 GIST patients had an accompanying solid tumour and that, in all of these cases, the stromal tumour was of stomach origin. Wronski et al. also determined that the co-occurrence rate of GISTs with other tumours was $15 \%$ and the co-occurrence rate with a secondary GIS cancer was $25 \%$; however, the association between small intestine-derived GIST cases and colorectal carcinomas is rare and limited to plain case reports [3]. Agaimy et al. reported that the incidence of small intestine-derived GISTs associated with other solid tumours is $8.3 \%$, versus $15.4 \%$ for stomach-derived GISTs [2]. A review of case reports in the literature showed that stromal tumours of the small intestine are mostly small and are associated with low to intermediate risk when classified according to Fletcher's risk classification [17]. (Tables 1 and 2) [4, 10, 12, 13, 18-23]. The presented case also had a small ileum-originated low-risk GIST. For GIST risk stratification is still debated. The classification proposed by Fletch-

Table 1. Fletcher risk classification [17]

\begin{tabular}{|lll}
\hline Risk group & Tumour size $(\mathrm{cm})$ & $\begin{array}{l}\text { Mitotic index } \\
(/ 50 \mathrm{hpf})\end{array}$ \\
\hline Very low risk & $<2 \mathrm{~cm}$ & $<5$ \\
\hline Low risk & $2-5 \mathrm{~cm}$ & $<5$ \\
\hline Intermediate risk & $<5 \mathrm{~cm}$ & $6-10$ \\
& $5-10 \mathrm{~cm}$ & $<5$ \\
\hline High risk & $>5 \mathrm{~cm}$ & $>5$ \\
& $>10 \mathrm{~cm}$ & Any mitotic \\
& Any size & activity \\
& & $>10$
\end{tabular}


Table 2. Demographic and clinicopathological features reported in the related literature on patients with small intestine-derived GIST coexisting with colorectal adenocarcinoma

\begin{tabular}{|c|c|c|c|c|c|c|c|c|c|}
\hline \multirow{2}{*}{$\begin{array}{l}\text { Authors } \\
\text { and reference } \\
\text { number }\end{array}$} & \multirow[t]{2}{*}{ Age } & \multirow[t]{2}{*}{ Sex } & \multicolumn{4}{|c|}{ Gastrointestinal stromal tumour } & \multicolumn{2}{|c|}{ Colorectal adenocarcinoma } & \multirow[t]{2}{*}{ Coexistence } \\
\hline & & & Localization & $\begin{array}{l}\text { Tumour } \\
\text { ize }(\mathrm{mm})\end{array}$ & $\begin{array}{l}\text { Mitotic index } \\
\text { (/50 hpf })\end{array}$ & Risk group & Localization & c-kit & \\
\hline Köver et al. [10] & $\begin{array}{l}78 \\
68 \\
68\end{array}$ & $\begin{array}{l}M \\
M \\
M\end{array}$ & $\begin{array}{l}\text { jejunum } \\
\text { jejunum } \\
\text { small bowel }\end{array}$ & $\begin{array}{c}25 \\
100 \\
9\end{array}$ & $\begin{array}{l}\text { UN } \\
\text { UN } \\
\text { UN }\end{array}$ & $\begin{array}{l}\text { IR } \\
H R \\
\text { VLR }\end{array}$ & $\begin{array}{c}\text { sigmoid } \\
\text { sigmoid } \\
\text { descending colon }\end{array}$ & $\begin{array}{l}\text { UN } \\
\text { UN } \\
\text { UN }\end{array}$ & $\begin{array}{c}\text { synchronic } \\
\text { synchronic } \\
\text { metachronous }\end{array}$ \\
\hline $\begin{array}{l}\text { Efstathioes } \\
\text { et al. [18] }\end{array}$ & 66 & M & $\begin{array}{c}\text { small bowel } \\
\text { local recurrence } \\
\text { liver }\end{array}$ & $\begin{array}{l}>100 \\
\text { UN } \\
\text { UN }\end{array}$ & $\begin{array}{l}8-10 \\
\text { UN } \\
<5\end{array}$ & $\begin{array}{l}\mathrm{HR} \\
H R^{*}\end{array}$ & caecum & UN & $\begin{array}{c}\text { synchronic } \\
\text { with recurrence }\end{array}$ \\
\hline $\begin{array}{l}\text { Melis } \\
\text { et al. [4] }\end{array}$ & $\begin{array}{l}86 \\
67\end{array}$ & $\begin{array}{l}F \\
F\end{array}$ & $\begin{array}{l}\text { jejunum } \\
\text { jejunum }\end{array}$ & $\begin{array}{l}40 \\
80\end{array}$ & $\begin{array}{l}1 \\
3\end{array}$ & $\begin{array}{l}\mathrm{LR} \\
\mathrm{IR}\end{array}$ & $\begin{array}{c}\text { caecum } \\
\text { ascending colon }\end{array}$ & $\begin{array}{l}\text { Neg. } \\
\text { Neg. }\end{array}$ & $\begin{array}{l}\text { synchronic } \\
\text { synchronic }\end{array}$ \\
\hline $\begin{array}{l}\text { Vahidi } \\
\text { et al. [19] }\end{array}$ & 76 & $\mathrm{~F}$ & ileum & 140 & 1 & $H R$ & caecum & UN & synchronic \\
\hline $\begin{array}{l}\text { Liszka } \\
\text { et al. [12] }\end{array}$ & $\begin{array}{l}63 \\
44 \\
66 \\
74\end{array}$ & $\begin{array}{l}M \\
M \\
F \\
F\end{array}$ & $\begin{array}{l}\text { small bowel } \\
\text { small bowel } \\
\text { small bowel } \\
\text { small bowel }\end{array}$ & $\begin{array}{l}\text { UN } \\
\text { UN } \\
\text { UN } \\
\text { UN }\end{array}$ & $\begin{array}{l}\text { UN } \\
\text { UN } \\
\text { UN } \\
\text { UN }\end{array}$ & $\begin{array}{l}\text { LR } \\
V L R \\
V L R \\
V L R\end{array}$ & $\begin{array}{l}\text { rectum } \\
\text { colon, UN } \\
\text { rectum } \\
\text { colon, UN }\end{array}$ & $\begin{array}{l}\text { UN } \\
\text { UN } \\
\text { UN } \\
\text { UN }\end{array}$ & $\begin{array}{l}\text { synchronic } \\
\text { synchronic } \\
\text { synchronic } \\
\text { synchronic }\end{array}$ \\
\hline $\begin{array}{l}\text { Gopal } \\
\text { et al. [20] }\end{array}$ & 77 & $\mathrm{~F}$ & jejunum & UN & 0 & $L R$ & sigmoid & UN & synchronic \\
\hline $\begin{array}{l}\text { Kosmidis } \\
\text { et al. [21] }\end{array}$ & 69 & $M$ & leckel's diverticulu & um 75 & $0-1$ & IR & rectosigmoid & UN & synchronic \\
\hline $\begin{array}{l}\text { Karoui } \\
\text { et al. [22] }\end{array}$ & 52 & M & jejunum & Cystic & UN & $L R$ & sigmoid & UN & synchronic \\
\hline $\begin{array}{l}\text { Chiu } \\
\text { et al. [23] }\end{array}$ & 84 & $\mathrm{~F}$ & ileum & 56 & UN & LR & colon, UN & Neg. & synchronic \\
\hline $\begin{array}{l}\text { Gonçalves } \\
\text { et al. [13] }\end{array}$ & $\begin{array}{l}24 \\
77\end{array}$ & $\begin{array}{l}F \\
F\end{array}$ & $\begin{array}{l}\text { small bowel } \\
\text { small bowel }\end{array}$ & $\begin{array}{c}90 \\
8\end{array}$ & $\begin{array}{l}\text { UN } \\
\text { UN }\end{array}$ & $\begin{array}{l}I R \\
V L R\end{array}$ & $\begin{array}{l}\text { colon, UN } \\
\text { colon, UN }\end{array}$ & $\begin{array}{l}\text { UN } \\
\text { UN }\end{array}$ & $\begin{array}{l}\text { metachronous } \\
\text { synchronic }\end{array}$ \\
\hline Our case & 78 & $M$ & ileum & 200 & 0 & $L R$ & caecum & focal & synchronic \\
\hline
\end{tabular}

er is still used today and in 2008 was revised by Joensuu [24]. All of the risk stratification systems proposed so far have emphasized the value of tumour size, mitotic count and anatomical site for risk estimation, at the same time appreciating the difficulty of classifying individual tumours as either benign or malignant [25].

Why GISTs are seen with other malignant tumours is not well understood. The hypothesis, based on a few experimental studies, is that a single carcinogen or carcinogenic pathway plays a role in the neoplastic proliferation of cell series from different histological subtypes [4]. Taking this into account, it can be suggested that cell stimulation is achieved via the same carcinogenic factor during the proliferation of both epithelial and stromal cells.

Melis et al. concluded that contemporary research data showing that mutation is a predisposing factor in neoplastic progression, and is the common mechanism in the pathogenesis of GIST and colorectal adenocarcinomas, are inconclusive [4]. The genetic pathways in the tumourigenesis of two different neoplasms (GIST and colorectal adenocarcinoma) being different was suggested as a probable cause; however; although the number of cases is limited, some researchers have reported that they could not rule out the possibility that this association is not coincidental.
Both colon cancer and GIST have a clear familial predisposition, excluding the well-known hereditary form [4]. One of the two most important pathways of colorectal carcinogenesis is chromosomal instability and this genetic alteration accounts for more than $85 \%$ of all sporadic colorectal cancer cases $[4,26,27]$. The other genetic pathway is mitochondrial instability, which is responsible for approximately $15 \%$ of all colorectal cancers. In colorectal carcinomas DNA mismatch repair genes, and APC, DCC, p53, and K-ras gene mutations are frequently responsible for carcinogenesis due to these 2 genetic alterations. Despite this, these gene mutations are not involved in GIST progression [4, 26]. Mutations associated with c-kit protein, which is a transmembrane protein that acts as a receptor for stem cell growth factor (SCF), play a role in GIST carcinogenesis as proto-oncogenesis. Activation of c-kit protein by its natural ligand (SCF) plays an important role in cellular transformation and differentiation, including cell proliferation and survival, adhesion, and chemotaxis [4, 26].

The literature includes two different arguments concerning c-kit protein expression in colorectal carcinogenesis. Bellone et al. posit that there is c-kit protein and SCF overexpression in colonic cancer cells and that c-kit protein activation reinforces the growth, migration, and inva- 
siveness of colon cancer cells [26]. Sammarco et al. reported that nearly $30 \%$ of colorectal cancer patients have c-kit protein expression [27]. On the other hand, some researchers suggest that human colorectal cancer cells rarely express c-kit protein. Singer et al. reported that only 4 of 72 patients (6\%) with colorectal cancer had c-kit protein overexpression [28], whereas this rate was $1.6 \%$ in Reed et al.'s study [29]. Melis et al. [4], and Chiu et al. [23] studied c-kit protein expression in colorectal adenocarcinoma patients, but did not observe positive staining in colorectal carcinomas (Table 2). In the presented case colon adenocarcinoma cells focally stained with c-kit protein. Determination of the existence of a role for c-kit protein in the progression of colon adenocarcinoma could lead to a definitive conclusion about the coexistence of these two tumours of the same tissue.

As a result, it would not be wrong to deduce that separate malignancies could occur along with GISTs and could be misleading in the evaluation of the clinical course. Surgical treatment and the management of liver metastases that can occur during the follow-up of synchronously diagnosed colorectal adenocarcinoma and GIST remain a major problem. We think that identifying the common pathway of colorectal carcinomas and GISTs via carcinogenesis-related research is of major importance and that detailed exploration during intra-abdominal tumour surgery should not be neglected.

Funding: None.

\section{References}

1. Agaimy A, Wuensch PH. Gastrontestinal stromal tumours in patients with other-type cancer: A mere coincidence or an etiological association? A study of 97 GIST cases. Z Gastroenterol 2005; 43: 1025 30.

2. Agaimy A, Wünsch PH, Sobin LH, Lasota J, Miettinen M. Occurrence of other malignancies in patients with gastrointestinal stromal tumors. Semin Diagn Pathol 2006; 23: 120-9.

3. Wronski M, Wroblewska BZ, Gornicka B, Cebulski W, Slodkowski M, Wasiutynski A, Krasnodebski IW. Syncronous occurence of gastrointestinal stromal tumors and other primary gastrointestinal neoplasms. World J Gastroenterol 2006; 12: 5360-2.

4. Melis M, Choi EA, Anders R, Christiansen P, Fichera A. Synchronous colorectal adenocarcinoma and gastrointestinal stromal tumor (GIST). In J Colorectal Dis 2007; 22: 109-14.

5. Mazur MT, Clark HB. Gastric stromal tumors. Reappraisal of histogenesis. Am J Surg Pathol 1983; 7: 507-19.

6. Kindblom LG, Remotti HE, Aldenborg F, Meis-Kindblom JM. Gastrointestinal pacemaker cell tumor (GI- PACT): gastrointestinal stromal tumors show phenotypic characteristics of the interstitial cells of Cajal. Am J Pathol 1998; 152: 1259-69.

7. Soyuer I, Tasdemir A, Ozturk F, Gursoy S, Dikilitas M, Dogu GG, Soyuer S, Karahan I, et al. Multiple gastrointestinal stromal tumors and their association with other rare tumors: Case report. Turkiye Klinikleri J Med Sci 2010; 30: 361-7.

8. Nilsson B, Bümming P, Meis- Kindblom JM, Oden A, Dortok A, Gustavsson B, Sablinska K, Kindblom LG. Gastrointestinal stromal tumors: the incidence, prevalence, clinical course, and prognostication in the preimatinib era. A population-based study in western Sweden. Cancer 2005; 103: 821-9.

9. Au WY, Ho KM, Shek TW. Papillary renal cell carcinoma and gastrointestinal stromal tumor: aunique association. Ann Oncol 2004; 15: 843-4.

10. Köver E, Faluhelyi Z, Bogner B, Kalmar K, Horvath G, Tornoczky T. Dual tumours in the GI tract: synchronous and metachronous stro- mal (GIST) and epithelial/neuroendocrine neoplasms. Magy Onkol 2004; 48: 315-21.

11. Urbanczyk K, Limon J, Korobowicz E, et al. Gastrointestinal stromal tumors. A multicenter experience. Pol J Pathol 2005; 56: 51-61.

12. Liszka L, Zielinska Pajak E, Pajak J, Golka D, Husano J. Coexistence of gastrointestinal stromal tumors with other neoplasm. J Gastroenterol 2007; 42: 641-9.

13. Gonçalves R, Linhares E, Albagli R, Valadao M, Vilhena B, Romano S, Ferreira CG. Occurence of other tumors in patients with GIST. Surg Oncol 2010; 19: e140-3.

14. Bulusu VR, Caroll N, Pursglove S, Save V, Hardwick R. Gastrointestinal stromal tumors(GISTS) and other cancers: Cambrige GIST Study Group experince. J Clin Oncol 2010; 28 (15 supp): 10084 (abstract).

15. Yavuzer D, Sakirahmet D, Dabak R, Erdagi A, Karadayi N. Coexistence of gastrointestinal stromal tumors and malign epithelial tumors. Kartal Egitim Arastirma Hastanesi Tip Dergisi 2009; 20: 7-12.

16. Kalmar K, Tornoczky T, Poto L, Illenyi L, Kalmar Nagy K, Kassai M, Kelemen D, Horvath OP. Gastrointestinal stromal tumours in a single institute: is there an association to other gastrointestinal malignancies? Magy Seb 2004; 57: 251-6.

17. Fletcher CD, Berman JJ, Corless C, et al. Diagnosis of gastrintestinal stromal tumors: A consensus approach. Hum Pathol 2002; 33: 459-65.

18. Efstathios P, Athanasios P, Papaconstantinou I, Alexandros P, Frangisca S, Sotirios G, Evangelos F, Athanasios G. Coexistence of gastrointestinal stromal tumor (GIST) and colorectal adenocarcinoma: A case report. World J Surg Oncol 2007; 5: 96-100.

19. Vahidi S, Rakhshan A. Synchronous occurrence of small intestinal stromal tumor and cecal adenocarcinoma. Arch Iranian Med 2008; 11: $665-8$.

20. Gopal SV, Langcake ME, Johnton E, Salisbury ELC. Synchronous association of small bowel stromal tumour with colonic adenocarcinoma. ANZ J Surg 2008; 78: 827-8.

21. Kosmidis C, Efthimiadis C, Levva S, et al. Synchronous colorectal adenocarcinoma and GIST in Meckel's dicerticulum: an unusual association. World J Surg Oncol 2009; 7: 33.

22. Karoui S, Ouaz A, Rebai W, et al. Syncronous occurence of colonic intraepithelial neoplasia and small bowel stromal tumour. AJG 2009; 10: $155-7$.

23. Chiu HH, Huang TC, Liu YW, Ko TL, Lu NK. Syncronous ileal stromal tumor (GIST) and colonic adenocarcinoma J Intern Med Taiwan. 2009; 20: 260-3.

24. Joensuu H. Risk stratification of patients diagnosed with gastrointestinal stromal tumor. Hum Pathol 2008; 39: 1411-9.

25. Agaimy A. Gastrointestinal stromal tumors (GIST) from risk stratification systems to the new TNM proposal: more questions than answers? A review emphasizing the need for a standardized GIST reporting. Int J lin Exp Pathol 2010; 3: 461-71.

26. Bellone G, Carbone A, Sibona N, Bosco O, Tibaudi D, Smirne C, Martone T, Gramigni $\mathrm{C}$, et al. Aberrant activation of c- kit protects colon carcinoma cells against apopitosis and enhances their invasive potential. Cancer Res 2001; 61: 2200-6.

27. Sammarco I, Capurso G, Coppola C, et al. Expression of the protooncogene c- kit in normal and tumor tissues from colorectal carcinoma patients. Int J Colorectal Dis 2004; 19: 545-53.

28. Singer CF, Hudelist G, Lamm W, Mueller R, Czerwenka K, Kubista E. Expression of tyrosine kinases in human malignancies as potential targets for kinase-specific inhibitors. Endocr Relat Cancer 2004; 11: 861-9.

29. Reed J, Ouban A, Schickor FK, Muraca P, Yeatman T, Coppola D. Immunohistochemical staining for c- kit (CD117) is a rare event in human colorectal carcinoma. Clin Colorectal Cancer 2002; 2: 119-22.

\section{Address for correspondence}

\section{Ozgur Tanriverdi}

Mugla Devlet Hastanesi-Mugla

Universitesi Arastirma ve Uygulama Merkezi,

Medikal Onkoloji Bolumu,

48000 Mugla, Turkey

e-mail: ozgurtanriverdi@hotmail.com 